\title{
Miranda
}

Revue pluridisciplinaire du monde anglophone /

Multidisciplinary peer-reviewed journal on the English-

speaking world

15 | 2017

Lolita at 60 / Staging American Bodies

\section{Christine Savinel, Gertrude Stein : Autobiographies intempestives}

\section{Monica Latham}

\section{OpenEdition}

\section{Journals}

\section{Electronic version}

URL: http://journals.openedition.org/miranda/10550

DOI: $10.4000 /$ miranda. 10550

ISSN: 2108-6559

Publisher

Université Toulouse - Jean Jaurès

\section{Electronic reference}

Monica Latham, "Christine Savinel, Gertrude Stein : Autobiographies intempestives", Miranda [Online], 15 | 2017, Online since 19 September 2017, connection on 16 February 2021. URL: http:// journals.openedition.org/miranda/10550 ; DOI: https://doi.org/10.4000/miranda.10550

This text was automatically generated on 16 February 2021.

\section{cc) (i) () $\Theta$}

Miranda is licensed under a Creative Commons Attribution-NonCommercial-NoDerivatives 4.0 International License. 


\title{
Christine Savinel, Gertrude Stein : Autobiographies intempestives
}

\author{
Monica Latham
}

\section{REFERENCES}

Savinel, Christine, Gertrude Stein : Autobiographies intempestives (Paris : Editions Rue D’Ulm/Presses de l'Ecole Normale Supérieure, 2017), 246 p, ISBN : 9782728805662

1 Gertrude Stein: Autobiographies intempestives offers exemplary scholarship on Gertrude Stein's autobiographical oeuvre. Chistine Savinel scrutinises the multiple facets of a cubist-like self-portrait painted by the prominent American author, an iconic figure at the heart of a vibrant artistic environment at the beginning of the twentieth century in Paris. Stein's “autobiographical enterprise" (15) amounts to a literary revolution, similar to her friend Picasso's geometrical representation of the author in his 1906 "Portrait of Gertrude Stein". The subject's mask-like face suggests the artist's inability to reveal her truth and access her interiority. Likewise, despite the multiplication of autobiographical poses in her oeuvre, Stein remains an elusive subject who both displays and dissimulates herself. Savinel leads us through Stein's autobiographical workshop and demonstrates that out of the multiplicity of fragmentary, partial, direct or oblique glimpses we are shown, the modernist author's "inopportune" autobiographical forms compose a consistent personal, national, literary, and aesthetic identity.

2 The monograph consists of an introduction, six substantial chapters and a conclusion. In her introduction, Savinel outlines the wide scope of her book that sets out to examine some of Stein's writings in which the autobiographical propensity appears, be it openly declared or thinly veiled. Savinel maps out and temporally delimits her corpus out of Stein's vast and varied oeuvre to focus especially on four major works revolving around questions of autobiography: The Autobiography of Alice B. Toklas (1933), Four in America (1934), The Geographical History of America (1936), and Everybody's 
Autobiography (1937). The first and last autobiographical landmarks-more accessible and popular-of this creative spectrum temporarily enclose more elitist and experimental works, but Savinel evinces that they all have in common Stein's creative strategy of hiding the self behind other subjects. Stein's personal letters as well as other additional writings are taken into account in order to highlight her "interior landscape" (15): essays (Lectures in America [1935]; Narration [1935]), a play (Four Saints in Three Acts [1927]), and her only detective novel (Blood on the Dining Room Floor [1933]). The autobiographical dimension crosses and brings together all these eclectic texts in which the author's personal reflexions resurface in indirect, unexpected ways. Savinel thoroughly investigates the nature of the Steinian autobiography, its displacements, detours, and contours, as well as its "inopportune" ramifications into other genres. The felicitous subtitle of the monograph, "Autobiographies intempestives", reflects Stein's unique autobiographical project: a disconcerting, incongruous and devious literary enterprise to stage and represent herself.

3 The first chapter of this monograph, "Faux témoignages", aims at exposing the "falseness" of Stein's autobiographical testimonies. Savinel mainly focuses on the literary ventriloquism at the heart of The Autobiography of Alice B. Toklas, that is to say Stein's hiding under her partner's identity in order to write a third-person autobiography and use it as a tribune from which she imparts her vision on art and creation. Savinel examines the immediate reception of this autobiography, especially the controversies triggered by Stein's opinions about artists from her entourage. Some of them question the truthfulness of their representations as well as Stein's inaccurate recording of historical truth, and voice their discontent in Témoignage contre Gertude Stein. By closely analysing Stein's stance and statements on writing her life, Savinel points out essential questions about the impossibility of being oneself when writing an autobiography and the limits of true and complete self-disclosure; hence, for Stein, the necessary devious literary game of borrowing another voice and identity to indirectly unveil herself and speak her truth.

4 While the previous chapter deals with other people's reactions to Stein's Autobiography of Alice B. Toklas, Chapter 2, "La place du mort", starts with Stein's own reaction to its reception and her writer's block (her dying and drying inspiration) about which she paradoxically abundantly writes in her second declared yet oblique autobiography, Everybody's Autobiography. After the successful reception of the first autobiography, Stein's written flow is paralysed, and Savinel contends that this amounts to an identity crisis for a writer who is defined by the flow of written words she has written, is writing and will write. For this, Savinel offers a detailed close reading of Stein's text, with an attentive eye on its materiality and movement, its breathing spaces, language, "grammar of crisis" (67), punctuation, syntax, and structure that participate in the expression of the author's strenuous effort to write.

5 Savinel demonstrates that Stein retrospectively casts doubts on the truthfulness of her first autobiography and reveals its fictitious nature by drawing analogies with Robinson Crusoe: "nothing is entirely real in autobiography and nothing is entirely fictitious in Robinson Crusoe" (70). Savinel underlines the lack of factual information for an autobiography, for its author is more interested in the evolution of her development and "apprenticeship as a genius" (81), and in questions of fluctuating memory, by definition inaccurate and untrustworthy. Autobiography is thus seen as fiction about oneself. Savinel further discusses the penetrating metacreative discourse to be found in 
Blood on the Dining Room Floor, a curious detective novel that draws on real events, and concludes that the author's inability to lead the investigation is ironically going to finally de-block and unleash her creative flow, her literary and linguistic experimentation. In this chapter, Savinel dwells on various examples in which Stein replaces, alienates, metaphorically "kills" people in her entourage (her brother Leo, friends, and collaborators) and performs identity substitutions and creative thefts in order to stage her own self and liberate her literary production.

6 In chapter 3, "Le général”, Savinel's starting point for her analysis of Stein's multiple autobiographical stances is Everybody's Autobiography. She minutely examines Stein's penchant for generalisations and indeterminacy, as well as the idiosyncratic Steinian grammar, which is intrinsically linked to the author's mode of thinking and writing. She further offers an analysis of Stein's own reflexions on her name, her identity stemming from family genealogy and filiation. Within such identity considerations, Savinel inserts an astute analysis of Four in America, a "biographical fantasy" (124), and an appropriate case to study for its original autobiographical dimensions. Stein fictionalises the lives of four American figures and imagines four "improbable" destinies for them, thus changing the course of their real lives and playing with their identities, as well as historical and biographical reality. Savinel contends that Four in America actually constitutes facets of Stein's self-portrait, as the four fictional portraits reflect her own American identity and offer "biographical, aesthetic and critical analogies" (121) with her own personal life. The autobiographical subtext thus underlies the ensemble of this fanciful literary production.

7 Chapter 4, "L'Amérique: géographie du hors-temps", focuses on Stein's Geographical History of America, another formal variation on the genre of autobiography in which Stein meditates about a-temporal interiority and personal identity shaped by origin and history. Savinel offers a thorough study of the relationships Stein establishes between biography and autobiography, personal and collective, interiority and exteriority, human mind and human nature, and explains that the Steinian autobiography exhibits tendencies towards temporal generalities, abstraction and geographical and historical de-contextualisation. Savinel also makes references to Narration, which gathers Stein's four conferences given in Chicago in 1935, in which questions about writing history are essential. Savinel argues that for Stein writing autobiography and history is similar insofar as they both consist in interiorising external events. This leads Stein to reconsider her American interiority and the nature of her "Americanness" (162), and ponder how much it is accounted for by human nature in general.

8 The interdependence between geography and identity is also a topic discussed in chapter 5, "Folie de la reconnaissance". Savinel follows Stein's geographical displacement and points out her disorientation during her American tour in 1935. The author's position as a public celebrity prompts musings about her American identity, about the adverbial motifs of "here", "there", "where", about her insularity as a prerequisite to her creativity, as well as about her "recognition" and "nonrecognition". Savinel asserts that Stein's non-recognition of her American territory has an impact on her writing, as confusion and malaise are reflected in her discourse and her use of a tortuous grammar and syntax. On the other hand, Stein's recognition as a "genius" and a creator of valuable, original works makes her reflect on the attributes of masterpieces which go beyond the author's identity and time; obliterating the self is 
thus paramount in the act of creation. Hence, being recognised by the public interferes with creativity. Savinel pores over such sharp observations and comments on the author's growing popularity in America, and shows how Stein is her own spectator and astute evaluator of her image and oeuvre.

According to Savinel, meditation is the essence of the Steinian autobiography, since all her autobiographical texts display reflexions about people, things, events, places, creation, language, literature and writing. In the last chapter of her monograph, "La méditation infinie", Savinel analyses the relationship between Stein's meandering, slow flow of thought and her use of an idiosyncratic punctuation to create meaning and rhythm. She offers the reader fine studies of the anatomy of the Steinian sentence, dissecting and interpreting its fluidity and sound effects. The Steinian autobiography is thus a recording of the author's meditations and reflexions on her own processes of thinking and creating; it does not display the materiality, exteriority and intimacy of the body, but scrutinises the mental interiority and the dynamics of her thoughts.

In each chapter of this intense monograph, Savinel investigates a plurality of aspects related to the specific themes announced in her titles that revolve around the central question of identity. We see how the icon of Gertrude Stein is built by Gertrude Stein herself, although we are never given a simple, straight-forward self-portrait. As an expert art and literary critic, Savinel guides us into Stein's intricate autobiographical poses and accounts and points out features that the modernist author skilfully dissimulates behind a variety of masks, filters, oblique representations, veiled truths, ventriloquism and convoluted discourses. Savinel has a comprehensive view of her subject, but also pauses on the Steinian text and magnifies it to offer us minute, illuminating close-reading analyses. As such, this book constitutes a valuable contribution to Gertude Stein studies in France and will appeal to an academic audience interested in Stein and avant-garde art and literature at the beginning of the twentieth century.

\section{INDEX}

Mots-clés: autobiographie, identité, biographie, histoire, géographie, expérimentation littéraire, expérimentation linguistique, avant-garde, cubisme, témoignage, vérité, méditations, intériorité, signature steinienne

Keywords: autobiography, identity, biography, history, geography, literary experimentation, linguistic experimentation, avant-garde, cubism, testimony, truth, meditations, interiority, Steinian signature 
AUTHORS

MONICA LATHAM

Professeur

Université de Lorraine

monica.latham@univ-lorraine.fr 